\title{
Pengaruh Dana Otonomi Khusus dan Pendapatan Asli Daerah terhadap Indeks Pembangunan Manusia di Provinsi Aceh Tahun 2008-2020
}

\author{
Arisa Arispen*, Dewi Rahmi \\ Prodi Ilmu Ekonomi dan Bisnis, Fakultas Ekonomi dan Bisnis, Universitas \\ Islam Bandung, Indonesia. \\ *arisaarispen@gmail.com,dewirahmi@unisba.ac.id
}

\begin{abstract}
Low regional fiscal independence, especially in obtaining Regional Original Revenue, is a regional financial problem for the Aceh Province which is still a target in the 2017-2022 (RPJMD). These problems have given rise to various development problems such as education, health and a decent standard of living for humans. Central transfer assistance through the Aceh Special Autonomy Fund is present as an aggressive government program that is expected to be able to accelerate development as seen through the increase in the Human Development Index (HDI). This article aims to analyze how the influence of the Aceh Special Autonomy Fund and Regional Original Income on the Human Development Index (HDI) in Aceh Province in 2008-2020. The analytical method used is quantitative and uses panel data analysis with a Fixed Effect Model (FEM) approach, which is obtained based on the results of the Chow test and Hausman test. The results showed that simultaneously (f-test) Aceh Special Autonomy Fund and Regional Original Income had a significant effect with a prob f-statistic of 0.000000 . Partially (t-test), Aceh Special Autonomy Fund has a significant negative effect of -1.383449 on HDI, and Regional Original Income has a significant positive effect of 2.179206 on HDI. This shows that the increase in regional fiscal capacity in the form of Regional Original Income and Aceh Special Autonomy Fund in Aceh Province, has a direct influence on the Human Development Index (HDI). However, the relationship between Aceh Special Autonomy Fund and development goals is an irony because it has a negative influence on HDI due to confusion in the regulation of distribution planning related to Aceh Special Autonomy Fund.
\end{abstract}

Keywords: Aceh Special Autonomy Fund, Regional Original Income, Human Development Index, panel data.

Abstrak. Kemandirian fiskal daerah yang rendah terutama dalam perolehan Pendapatan Asli Daerah (PAD), merupakan permasalahan keuangan daerah Provinsi Aceh yang hingga saat ini masih menjadi target dalam Rencana Pembangunan Jangka Menengah Daerah (RPJMD) Tahun 2017-2022. Permasalahan tersebut telah menimbulkan berbagai permasalahan pembangunan seperti pendidikan, kesehatan, dan standar hidup layak manusia. Bantuan transfer pusat melalui Dana Otonomi Khusus Aceh (DOKA) hadir sebagai program agresif pemerintah yang diharapkan mampu melaksanakan percepatan pembangunan yang dilihat melalui peningkatan Indeks Pembangunan Manusia (IPM). Artikel ini bertujuan untuk menganalisis bagaimana pengaruh Dana Otonomi Khusus Aceh (DOKA) dan Pendapatan Asli Daerah (PAD) terhadap Indeks Pembangunan Manusia (IPM) di Provinsi Aceh tahun 2008-2020. Metode analisis yang digunakan adalah kuantitatif dan menggunakan analisis data panel dengan pendekatan Fixed Effect Model (FEM), yang diperoleh berdasarkan hasil uji chow dan uji hausman. Hasil penelitian menunjukkan secara simultan (uji-f) DOKA dan PAD berpengaruh secara signifikan dengan prob f-statistik 0.000000. Secara parsial (uji-t), DOKA berpengaruh secara negatif signifikan sebesar -1.383449 terhadap IPM, dan PAD berpengaruh secara positif signifikan sebesar 2.179206 terhadap IPM. Hal ini menunjukkan dengan adanya peningkatan kapasitas fiskal daerah berupa PAD dan DOKA di Provinsi Aceh, memiliki pengaruh secara langsung terhadap Indeks Pembangunan Manusia (IPM). Namun keterkaitan DOKA dengan tujuan pembangunan menjadi sebuah ironi karena memberikan pengaruh negatif terhadap IPM yang disebabkan karena kesimpangsiuran regulasi perencanaan penyaluran terkait DOKA.

Kata Kunci: Dana Otonomi Khusus Aceh (DOKA), Pendapatan Asli Daerah (PAD), Indeks Pembangunan Manusia (IPM), data panel. 


\section{A. Pendahuluan}

Konsep hukum kenegaraan di Indonesia menetapkan daerah istimewa yang telah tercantum di dalam undang-undang. Pasal 18B UUD 1945 telah ditetapkan pemerintah pusat tentang pemberian hak Otonomi Khusus kepada satuan pemerintah daerah sebagai bentuk menghormati dan mengakui masing-masing pemerintah daerah yang bersifat khusus atau istimewa. Pemerintah daerah yang mendapatkan Otonomi Khusus dapat menjalankan pemerintahan daerah yang bersifat mandiri dalam artian memberikan kewenangan untuk mengatur dan mengurus urusan pemerintah daerahnya sendiri yang sesuai dengan peraturan undang-undang dasar 1945 (Saputra, 2020).

Provinsi Aceh merupakan provinsi yang di anugerahkan status Otonomi Khusus dengan diwujudkannya melalui UU No. 18 Tahun 2001. Adapun faktor-faktor yang menyebabkan Aceh mendapatkan perlakuan kebijakan asimetris dengan ditetapkannya sebagai daerah Otonomi Khusus, seperti; 1) Dedikasi dan perjuangan yang luar biasa dari Aceh selama perjuangan mempertahankan kemerdekaan; 2) Resolusi konflik pada kesepakatan MoU Helsinki di Finlandia; 3) Terjadinya bencana tsunami Aceh yang melanda ditahun 2004. Oleh karena itu, bentuk dari perlakuan kebijakan asimetris tersebut pemerintah pusat telah menetapkan kebijakan transfer ke daerah yang selalu dianggarkan di dalam setiap APBN. Pemberian transfer dana tersebut ditujukan sebagai bentuk pemberian kewenangan dalam pemanfaatan sumber pendanaan yang ada dalam bentuk alokasi Dana Otonomi Khusus Aceh (DOKA). Anggaran DOKA ditujukan untuk percepatan pembangunan Aceh dalam membiayai pembangunan infrastruktur, pemberdayaan ekonomi rakyat, pengentasan kemiskinan, serta pendanaan pendidikan, sosial, dan kesehatan yang kemudian mengarah pada kesejahteraan masyarakat (Maulana, 2019). Dengan kata lain, DOKA memiliki peranan dalam mendanai kebutuhan pemerintahan sehari-hari maupun dalam memberi pelayanan publik yang lebih baik kepada masyarakat.

Untuk mewujudkan pelayanan publik yang lebih baik tidaklah mudah dan seringkali dihadapkan berbagai permasalahan terkait DOKA. Pertama; pengelolaan DOKA bagi banyak penduduk asli Aceh seringkali dinyatakan tidak maksimal. Besaran DOKA yang diterima belum membuat Aceh menjadi lebih makmur atau lebih baik dibandingkan dengan provinsi lainnya. Kedua, pengelolaan DOKA terus mengalami tarik ulur dalam implementasinya. Kesimpang siuran regulasi dalam pengelolaan DOKA dapat menghambat percepatan pembangunan. Ketiga, DOKA yang diterima pemerintah Aceh berlaku untuk jangka waktu 20 tahun. Itu artinya proporsi jumlah DOKA yang diterima pemerintah Aceh harus dikelola secara optimal karena dana tersebut akan berakhir di tahun 2027. Permasalahan alokasi DOKA tersebut masih menjadi masalah dalam pembangunan Aceh terutama dalam membiayai sektor-sektor pembangunan manusia karena menyangkut kesejahteraan masyarakat. Spesifiknya, pemerintah daerah harus bisa mengalokasikan DOKA melalui pengeluaran pembangunan di sektor-sektor pendukung untuk meningkatkan Indeks Pembangunan Manusia (IPM).

Kemandirian fiskal pemerintah daerah Aceh masih menjadi isu strategis sebagaimana telah tercantum dalam Rencana Pembangunan Jangka Menengah Daerah (RPJMD) Provinsi Aceh Tahun 2017-2022. Aceh termasuk dalam kategori daerah yang belum mandiri dengan Indeks Kemandirian Fiskal senilai 0,1715. Kategori tersebut menggambarkan bahwa perolehan (Pendapatan Asli Daerah) PAD diseluruh pemerintah kabupaten/kota di Provinsi Aceh belum mampu untuk membiayai pelaksanaan pembangunan dan peningkatan kualitas pelayanan kepada masyarakat. Mengingat masyarakat telah memberikan sumber daya kepada daerah berupa pembayaran pajak daerah, restribusi dan lain-lain, namun pemerintah daerah selaku pengelola dalam hal ini, sudah seharusnya memberikan timbal balik kepada masyarakat dalam bentuk pelayanan publik yang didanai oleh pendapatan daerah itu sendiri (Sarkoro, 2016).

Disisi lain, adanya ketergantungan yang tinggi terhadap transfer dana yang sebetulnya dapat mengakibatkan dampak yang sangat fatal bagi kelangsungan suatu daerah dalam menjalankan roda kepemerintahannya. Seandainya pemberhentian transfer dana DOKA dari pusat dihentikan dan tidak dibekali dengan kemampuan daerah dalam memaksimalkan pendapatan asli daerahnya, maka roda kepemerintahan daerah akan mengalami krisis keuangan yang pelik. Sehingga kesejahteraan masyarakat dapat menurun (Wardiah, 2018). Pemerintah 
Aceh masih dihadapkan pengelolaan keuangan daerah yang belum mandiri secara fiskal terutama dalam Pendapatan Asli Daerahnya yang merupakan salah satu faktor penyebab munculnya permasalahan pembangunan Aceh.

Ketidakoptimalan perolehan PAD disebabkan karena tingkat kegiatan produktif di provinsi Aceh yang masih rendah. Pajak dan retribusi daerah belum dapat diandalkan oleh pemerintah Aceh sebagai sumber pembiayaan desentralisasi. Hal ini karena ketidakmampuan kegiatan Intensifikasi dan Ekstensifikasi sumber-sumber PAD yang disebabkan oleh beberapa hal: 1) Pemerintah Aceh masih mengalami ketergantungan fiskal dari pemerintah pusat meskipun adanya kecenderungan peningkatan PAD dalam beberapa tahun terakhir. 2) Pemerintah Aceh belum sepenuhnya mampu menggali potensi daerah sebagai sumber penerimaan daerah sekaligus dianggap belum mencapai kemandirian daerah. 3) Belum maksimalnya pemetaan dan belum optimalnya penggalian potensi sumber daya ekonomi dan potensi objek-objek PAD sebagai sektor unggulan untuk menjadi kekuatan dan daya saing daerah (core competence). Tabel 1.1 menunjukkan perolehan PAD masih sangat minim bila dibandingkan dengan DOKA yang ditransfer dari pusat.

Tabel 1. Realisasi Dana Otonomi Khusus Aceh (DOKA) dan Pendapatan Asli Daerah (PAD) serta Indeks Pembangunan Manusia di Provinsi Aceh Tahun 2008-2020

\begin{tabular}{|c|c|c|c|}
\hline \multirow{2}{*}{ Tahun } & PAD & DOKA & \multirow{2}{*}{ IPM } \\
\hline & \multicolumn{2}{|c|}{ (rupiah) } & \\
\hline 2008 & 720.000 .000 .000 & 3.590 .000 .000 .000 & 67,09 \\
\hline 2009 & 740.000 .000 .000 & 3.730 .000 .000 .000 & 67,00 \\
\hline 2010 & 796.949 .424 .000 & 3.850 .000 .000 .000 & 67,09 \\
\hline 2011 & 805.179 .231 .000 & 4.510 .000 .000 .000 & 67,45 \\
\hline 2012 & 901.174 .000 .000 & 5.480 .000 .000 .000 & 67,81 \\
\hline 2013 & 1.309 .623 .000 .000 & 6.220 .000 .000 .000 & 68,30 \\
\hline 2014 & 1.779 .626 .000 .000 & 6.820 .000 .000 .000 & 68,81 \\
\hline 2015 & 1.560 .000 .000 .000 & 7.060 .000 .000 .000 & 69,45 \\
\hline 2016 & 2.060 .180 .945 .000 & 7.707 .216 .942 .000 & 70 \\
\hline 2017 & 2.276 .305 .568 .000 & 7.971 .646 .295 .000 & 70,60 \\
\hline 2018 & 2.359 .385 .393 .000 & 8.029 .791 .593 .000 & 71,19 \\
\hline 2019 & 2.698 .912 .471 .000 & 8.344 .873 .155 .050 & 71,90 \\
\hline 2020 & 2.184 .607 .197 .000 & 6.514 .403 .272 .000 & 71,99 \\
\hline
\end{tabular}

Tabel 1. menunjukkan perbandingan antara DOKA, PAD, dan IPM di Provinsi Aceh tahun 2008-2020. Perolehan DOKA dan PAD sepanjang tahun 2008-2020 menunjukkan peningkatan disetiap tahunnya yang kemudian diikuti oleh peningkatan IPM. Namun jika ditinjau kembali, perolehan DOKA yang meningkat sebesar 7 (tujuh) persen per-tahunnya tidak menunjukkan peningkatan yang signifikan terhadap IPM Aceh. Bahkan peningkatan IPM di Provinsi Aceh selama tahun 2008-2020 cenderung melambat. Adapun perolehan PAD yang masih berjalan stagnan walaupun terjadi peningkatan namun sangat tipis. Hal ini karena regulasi 
dan pemanfaatan kekayaan Aceh masih rendah terutama dalam pemungutan pajak yang masih bersifat manual dan belum berdasarkan teknologi informasi. Restribusi Aceh dan lain-lain pendapatan asli daerah belum tergali secara optimal dari kontribusinya baik dari sektor pertanian, kehutanan, dan perikanan serta industri pengolahan terhadap struktur perekonomian yang diterima Aceh. Perolehan PAD hanya berkontribusi terhadap APBD Aceh dengan ratarata 13,42 persen pertahun. Sedangkan perolehan DOKA memiliki kontribusi terbesar dalam APBD Aceh dengan rata-rata 58,06 persen pertahun. Hal ini menggambarkan ketergantungan atas pendapatan DOKA terhadap APBD Aceh masih tinggi. Pelayanan publik akan dapat direalisasikan jika pendapatan daerah memadai. Jika DOKA tidak ada, dilihat dari kondisi PAD Aceh saat ini belum tentu dapat meningkatkan IPM Aceh melalui pelayan publik (Firdaus, 2013).

Lebih lanjut, IPM Aceh mengalami peningkatan, namun masih cukup berjalan stagnan. Terlihat di tahun 2008-2012 IPM Aceh mengalami peningkatan namun peningkatannya sangat tipis bahkan sempat mengalami penurunan. Kemudian di tahun 2013-2020, IPM Aceh mengalami peningkatan namun peningkatan ini cenderung lambat. Bahkan perlambatan ini kemudian mempengaruhi peringkat IPM Aceh secara nasional selama tahun 2013 hingga tahun 2020 yang selalu menduduki peringkat ke 11. Peringkat IPM Aceh secara nasional tidak mengalami peningkatan tetapi tidak juga mengalami penurunan (Saputra, 2020).

Perlambatan Indeks Pembangunan Manusia (IPM) di suatu daerah menggambarkan dua faktor yang mendasarinya. Pertama, disebabkan oleh kemampuan ekonomi disuatu daerah yang belum memadai. Semakin memadai kemampuan ekonomi dan kapasitas administrasi suatu daerah maka akan semakin layak daerah tersebut menangani berbagai pelayanan publik untuk meningkatkan kesejahteraan masyarakatnya. Kedua, desentralisasi pemerintahan belum mampu diterjemahkan oleh pemerintah daerah untuk meningkatkan kesejahteraan masyarakatnya (Setiawan, 2013). Dengan melihat permasalahan yang ada di provinsi Aceh, seperti kemampuan ekonomi dalam Pendapatan Asli Daerah (PAD) yang belum memadai serta Dana Otonomi Khusus Aceh (DOKA) yang masih dihadapkan permasalahan dalam tata kelolanya, hal ini menjadi faktor penyebab perlambatan IPM di Provinsi Aceh.

Berbagai permasalahan dalam perolehan PAD dan pengelolaan DOKA yang belum optimal masih menjadi masalah utama bagi pembangunan Aceh. Dikhawatirkan besaran dana yang dianggarkan oleh pemerintah setiap tahunnya diharapkan mampu menjadi stimulus bagi pembangunan di provinsi Aceh khususnya dalam bidang sumber daya manusia tetapi justru menciptakan kegagalan pelaksanaan pembangunan.. Untuk itu, tujuan dari penelitian dalam karya ilmiah ini adalah:

1. Untuk menganalisis pengaruh dana otonomi khusus dan pendapatan asli daerah terhadap indeks pembangunan manusia di $23 \mathrm{kab} / \mathrm{kota}$ di Provinsi Aceh tahun 2008-2020.

2. Untuk menganalisis seberapa besar pengaruh dana otonomi khusus dan pendapatan asli daerah terhadap indeks pembangunan manusia di 23 kab/kota di Provinsi Aceh tahun 2008-2020.

\section{B. Metodelogi}

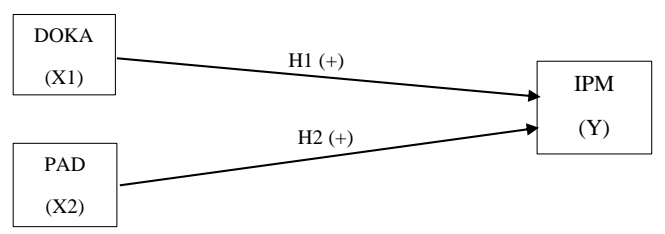

Gambar 1. Hipotesis Peneitian

Dalam penelitian ini penulis menggunakan pendekatan penelitian kuantitatif dengan data panel. Data diperoleh dari Laporan Badan Statistik dan Peraturan Gubernur Aceh serta jurnal yang berkaitan dengan kebutuhan penelitian. Data yang digunakan adalah PAD, DOKA, dan IPM kabupaten/kota selama Tahun 2008-2020. 
Pengujian hipotesis dalam penelitian ini menggunakan model analisis regresi berganda (Multiple Regression Analysis). Adapun dalam penelitian ini model persamaan regresi persamaan ditransformasikan ke dalam bentuk semi-log. Dimana sebelah kanan (variabel independen) ditransformasi ke dalam bentuk logaritma ( $\mathrm{Log}$ ), dan sebelah kiri persamaan regresi (variabel dependen) nilainya tetap (Ghozali, 2013). Model analisis dalam penelitian ini ditampilkan sebagai berikut:

$$
\mathrm{IPM}=\beta 0+\beta 1 \log (\mathrm{DOKA})+\beta 2 \log \mathrm{PAD}+\mu
$$

Dimana:

IPM : Indeks Pembangunan Manusia (IPM)

B0 : Konstanta

$\beta 1, \beta 2$ : Koefisien regresi

Log(DOKA) : Dana Otonomi Khusus Aceh (DOKA)

$\log (\mathrm{PAD})$ : Pendapatan Asli Daerah (PAD)

$\mu$ : Error, Variabel gangguan

Log : Logaritma Linier.

\section{Hasil dan Pembahasan}

Pada penelitian ini model yang dipilih adalah estimasi data panel berdasarkan Fixed Effect Model. Estimasi variabel IPM (Y) terhadap variabel DOKA (X1) dan PAD (X2) ditujukkan sebagai berikut:

Tabel 2. Hasil Uji Estimasi Data Panel

\begin{tabular}{|c|c|c|c|c|c|}
\hline Variable & Coefficient & $\begin{array}{ll}\text { Std. } & \text { Stror }\end{array}$ & t-Statistic & & Prob. \\
\hline $\mathrm{C}$ & 56.38668 & $\begin{array}{ll}4 & 2.50782\end{array}$ & 22.48430 & 0 & 0.000 \\
\hline LOGDOKA & -1.383449 & 0.09492 & -14.57413 & 0 & 0.000 \\
\hline LOGPAD & 1.909886 & 0.12797 & 14.92425 & 0 & 0.000 \\
\hline
\end{tabular}

Tabel 2 menunjukkan bahwa DOKA memiliki hubungan yang negatif dan berpengaruh signifikan terhadap IPM. Hasil ini menunjukkan bahwa adanya ketidaksesuaian penelitian ini dengan hipotesis yang telah dibangun. Selaras dengan penelitian Isnadi dan Fikriah (2020) yang menyatakan bahwa program alokasi penggunaan anggaran Dana Otonomi Khusus memberikan korelasi negatif terhadap Indeks Pembangunan manusia. Hasil temuannya menyatakan bahwa alokasi penggunaan anggaran Dana Otonomi Khusus yang terfokus pada sektor infrastruktur namun minimnya kuota yang akan dialokasikan pada pembangunan manusia terutama di sektor pendidikan menjadi faktor penyebab penurunan kesejahteraan masyarakat. Todaro dan Smith (2006) berpendapat bahwa pengeluaran publik untuk pembangunan manusia melalui penyediaan pelayanan dasar akan sangat memengaruhi kualitas human capital di masa yang akan datang. Modal manusia merupakan investasi produktif terhadap orang-orang; mencakup pengetahuan, keterampilan, kemampuan, dan gagasan. Pelayan publik akan sangat mempengaruhi bagaimana mutu dari pembangunan manusia. Jika alokasi pengeluaran publik tidak tepat sasaran, maka pengaruh dari pengeluaran tersebut terhadap pembangunan manusia di masa yang akan datang akan sangat kecil bahkan dapat terjadi penurunan.

Adapun hasil estimasi model menunjukkan bahwa PAD memiliki korelasi positif dan berpengaruh secara signifikan terhadap IPM kabupaten/kota di Provinsi Aceh. Hasil penelitian ini sejalan dengan teori yang mengungkapkan bahwa semakin besar pemerintah daerah mampu menggali sumber-sumber keuangan lokal melalui PAD maka akan sebanding dengan laju pembangunan di daerah tersebut. Jika pengelolaan pajak dapat dilakukan dengan efektif, maka tidak akan menghambat proses pembiayaan pembangunan fasilitas layanan publik bagi masyarakat. Hubungan emerintah daerah dengan masyarakat seperti hubungannya dalam perolehan PAD dengan pelayanan publik. Masyarakat sebagai prinsipal telah memberikan pajak daerah, retribusi dan sebagainya untuk dapat meningkatkan penerimaan daerah. Pemerintah 
daerah selaku pengelola dalam hal ini, sudah seharusnya memberikan timbal balik kepada masyarakat dalam bentuk pelayanan publik yang memadai, yang didanai oleh pendapatan daerah itu sendiri

\section{Kesimpulan}

Analisa data dalam hasil analisis dan pembahasan mengenai pengaruh Dana Otonomi Khusus Aceh (DOKA) dan Pendapatan Asli Daerah (PAD) terhadap Indeks Pembangunan Manusia (IPM) di provinsi Aceh tahun 2008-2020, maka kesimpulan yang dapat diambil pada penelitian ini ialah:

1. DOKA memiliki pengaruh negatif dan berpengaruh secara signifikan terhadap IPM. Hal ini karena alokasi DOKA dalam pelayanan publik lebih dominan untuk pembangunan fisik, sedangkan kuota untuk pembangunan manusia seperti pendidikan, kesehatan, atau program yang dapat meningkatkan kualitas hidup manusia tidak sebanyak pembangunan fisik. Sehingga alokasi DOKA masih dirasa tidak tepat sasaran walaupun pengaruhnya sangat besar dan menyebabkan penurunan terhadap IPM.

2. PAD memiliki pengaruh positif dan berpengaruh secara signifikan terhadap IPM. Hal ini karena alokasi PAD dalam pelayanan publik dapat membiayai pelayanan publik sehingga elemen dari IPM dapat meningkat. Semakin besar PAD maka belanja daerah juga meningkat dan akan lebih banyak pengeluaran untuk kesejahteraan masyarakat.

\section{Daftar Pustaka}

[1] Badan Pusat Statistik Provinsi Aceh. (2020). Indeks Pembangunan Manusia Provinsi Aceh.

[2] Badan Pusat Statistik Provinsi Aceh. (2021). Aceh Dalam Angka 2021.

[3] Ghozali, I. (2013). Aplikasi Analisis Multivariate dengan Program IBM SPSS 21 Update PLS Regresi. Badan Penerbit Universitas Dipenegoro.

[4] Gujarati, Damodar. 2012. Dasar-Dasar Ekonometrika. Jakarta:Salemba Empat.

[5] Halim, Abdul. (2007). Akuntansi Sektor Publik Akuntansi keuangan daerah, Edisi Revisi. Jakarta: Salemba Empat.

[6] Isnadi, N., \& Fikriah. (2019). Dampak Dana Otonomi Khusus Terhadap Tingkat Pertumbuhan Indeks Pembangunan Manusia di Provinsi Aceh. Jurnal Ilmiah Mahasiswa (JIM), 4(1), 29-37.

[7] Kementrian Dalam Negeri, 2020. Penggunaan Dana Otsus Aceh dan Dana Istimewa DIY.

[8] Republik Indonesia. 1998. TAP MPR Nomor XV/MPR/1998 tentang Penyelenggaraan Otonomi Daerah. Sekretariat Negara, Jakarta.

[9] Republik Indonesia. Pasal 18 B Ayat (1) UUD NRI 1945, Sekretariat Negara, Jakarta

[10] Saputra, M. H. (2020). Pengaruh Dana Otonomi Khusus Terhadap Indeks Pembangunan Manusia Kabupaten/Kota Di Provinsi Aceh. Quantitative Economics Journal, 3(4).

[11] Sarkoro, H., \& Zulfikar, Z. (2018). DANA ALOKASI KHUSUS DAN PENDAPATAN ASLI DAERAH TERHADAP INDEKS PEMBANGUNAN MANUSIA (Studi Empiris pada Pemerintah Provinsi se-Indonesia Tahun 2012-2014). Riset Akuntansi Dan Keuangan Indonesia, 1(1), 54-63. https://doi.org/10.23917/reaksi.v1i1.1972

[12] Setiawan, Muhammad Bahkti dan Hakim. 2013. INDEKS PEMBANGUNAN MANUSIA INDONESIA. Jurnal Economia. Volume 9, Nomor 1.

[13] Sidik, M. B. (2002). Dana Alokasi Umum - Konsep, Hambatan, dan Prospek di Era Otonomi Daerah. Jakarta: Kompas.

[14] Sugiyono. (2013). Metode Penelitian Kuantitatif, Kualitatif dan R\&D. Alfabeta.

[15] Todaro, M. P. (2011). Pembangunan Ekonomi. Erlangga.

[16] Undang-Undang Republik Indonesia No.11 Tahun 2006 tentang Pemerintahan Aceh. Qanun Aceh No.2 Tahun 2008 tentang Tata Cara Pengalokasian Tambahan Dana Bagi Hasil Minyak dan Gas Bumi dan Penggunaan Dana Otonomi Khusus. 
[17] United Nations Development Programme. (1996). Human Development Report 1996, Economic and Human Development. New York: Oxford University Press.

[18] Wardiah. (2018). Pengaruh Pendapatan Asli dan Belanja Modal terhadap Pertumbuhan Ekonomi di Provinsi Aceh. Jurnal Visioner dan Strategis, vol. 7 no. 1.

[19] Zulfan, \& Maulana, H. (2019). Gejala Fly Paper Effect di Provinsi Aceh Ditinjau Dari Dana Alokasi Umum Dan Dana Otonomi Khusus. Journal of Economic and Business Mulawarman University, Inovasi15(2): 188-197. 